\title{
Skill sets required for the management of military head, face and neck trauma: a multidisciplinary consensus statement
}

\author{
John Breeze, ${ }^{1,2}$ R Blanch, ${ }^{1,2}$ J Baden, ${ }^{2}$ A M Monaghan, ${ }^{2}$ D Evriviades, ${ }^{2}$ S E Harrisson, ${ }^{1,3}$ \\ S Roberts, ${ }^{1,2}$ A Gibson, ${ }^{4} \mathrm{~N}$ MacKenzie, ${ }^{5}$ D Baxter, ${ }_{1}^{1}$ A J Gibbons, ${ }_{1}^{6}$ S Heppell, ${ }^{5}$ \\ J G Combes, ${ }^{7}$ R F Rickard ${ }^{1,8}$
}

Academic Department of Military Surgery and Trauma, Royal Centre for Defence Medicine, Birmingham, UK ${ }^{2}$ Queen Elizabeth Hospital Birmingham, Birmingham, UK ${ }^{3}$ University Hospitals of North Midlands NHS Trust, Stoke, UK ${ }^{4}$ James Cook University Hospital, Middlesbrough, UK ${ }^{5}$ Queen Alexandra Hospital, Portsmouth, UK

${ }^{6}$ Peterborough District General Hospital, Peterborough, UK

${ }^{7}$ Royal Surrey County Hospital, Guildford, UK

${ }^{8}$ Derriford Hospital, Plymouth, UK

\section{Correspondence to} John Breeze, Academic Department of Military Surgery and Trauma, Royal Centre for Defence Medicine, Birmingham, UK; editor.jramc@bmj.com

Received 13 November 2017 Accepted 20 November 2017

Published Online First

10 January 2018

Check for updates

To cite: Breeze J, Blanch $\mathrm{R}$,

Baden J, et al.

J R Army Med Corps

2018:164:133-138.

\begin{abstract}
Introduction The evolution of medical practice is resulting in increasing subspecialisation, with head, face and neck (HFN) trauma in a civilian environment usually managed by a combination of surgical specialties working as a team. However, the full combination of HFN specialties commonly available in the NHS may not be available in future UK military-led operations, necessitating the identification of a group of skill sets that could be delivered by one or more deployed surgeons.

Method A systematic review was undertaken to identify those surgical procedures performed to treat acute military head, face, neck and eye trauma. A multidisciplinary consensus group was convened following this with military HFN trauma expertise to define those procedures commonly required to conduct deployed, in-theatre HFN surgical combat trauma management.
\end{abstract}

Results Head, face, neck and eye damage control surgical procedures were identified as comprising surgical cricothyroidotomy, cervico-facial haemorrhage control and decompression of orbital haemorrhage through lateral canthotomy. Acute in-theatre surgical skills required within 24 hours consist of wound debridement, surgical tracheostomy, decompressive craniectomy, intracranial pressure monitor placement, temporary facial fracture stabilisation for airway management or haemorrhage control and primary globe repair. Delayed in-theatre procedures required within 5 days prior to predicted evacuation encompass facial fracture fixation, delayed lateral canthotomy, evisceration, enucleation and eyelid repair.

Conclusions The identification of those skill sets required for deployment is in keeping with the General Medical Council's current drive towards credentialing consultants, by which a consultant surgeon's capabilities in particular practice areas would be defined. Limited opportunities currently exist for trainees and consultants to gain experience in the management of traumatic head, face, neck and eye injuries seen in a kinetic combat environment. Predeployment training requires that the surgical techniques described in this paper are covered and should form the curriculum of future military-specific surgical fellowships. Relevant continued professional development will be necessary to maintain required clinical competency.

\section{INTRODUCTION}

Wounds sustained from ballistic and blast trauma in the military environment are challenging to

\section{Key messages}

Head, face and neck (HFN) trauma in a civilian environment is usually managed by a combination of surgical specialties working as a team.

- Such a combination of HFN specialties may not be available in future UK military-led operations, necessitating the identification of a group of skill sets that could be delivered by one or more deployed surgeons.

- The identification of those skill sets required for deployment is in keeping with the General Medical Council's current drive towards credentialing consultants.

- This paper describes a multidisciplinary consensus agreement on those skills required to treat HFN trauma in the deployed military environment.

manage due to energy transfer, potential contamination and inconsistencies in the resources available to the treating surgeon. This is compounded in the head, face and neck (HFN) region by the complex regional anatomy and a requirement to optimise functional, physiological, aesthetic and psychological outcomes. In the UK, such wounds are usually managed in civilian major trauma centres (MTCs), where multiple surgical specialties are available and can complement each other in terms of their skill sets. There has been a drive within the Defence Medical Services (DMS) to place military surgeons within MTCs to optimise their knowledge in treating trauma. ${ }^{1}$ In conflicts during the 20th and early 21 st centuries, military field hospitals were sometimes manned by a 'head and neck team', highly reflective of civilian practice. These teams included ear, nose and throat, maxillofacial, neurosurgeons, ophthalmic surgeons and plastic surgeons.

The management of acute injuries to the HFN region on operations is described within the concept of the Operational Patient Care Pathway. ${ }^{2}$ This is a single and coherent end-to-end healthcare system, operating from point of injury to treatment within the UK following evacuation. It encompasses the concepts of immediate care, damage control surgery (DCS) and in-theatre surgery. ${ }^{2}$ 
Immediate care is that provided by medics in the field or on warships and in terms of the HFN region comprises interventions such as emergency cricothyroidotomy and haemostatic dressings for penetrating wounds. DCS is the concept by which 'patients are rapidly assessed, life-saving resuscitation undertaken and only abbreviated surgery performed'. ${ }^{3}$ DCS is a component of damage control resuscitation (DCR), which is 'a systemic approach to major trauma combining the $\langle\mathrm{C}\rangle \mathrm{ABC}$ (catastrophic bleeding, airway, breathing, circulation) paradigm in order to minimise blood loss, maximise tissue oxygenation and optimise outcome'. ${ }^{5}$ The Operational Patient Care Pathway provides a planning metric that suggests such DCS procedures take 'up to one hour but certainly less than two'.' 'In-theatre' surgical procedures comprise those that 'halt physiological deterioration to allow safe evacuation to a definitive care facility', as well as 'appropriate definitive surgery for patients ineligible for evacuation out of theatre. ${ }^{4} 6$

As part of the Strategic Defence and Security Review (SDSR), the Surgeon General in 2014 set out his vision for the composition of the DMS in the year 2020. It predicted 'changes in the size, structure, and composition of the DMS that are needed in response to recent advances in military medicine, the changing nature of contemporary conflict and current financial constraints'. ${ }^{7}$ A requirement for highly mobile medical facilities was identified, which will in turn necessitate rationalisation of those clinicians capable of providing that care. Therefore, only one or two of the surgical specialties previously described as comprising the head and neck team are likely to be present at any one time. In addition, the rapid timelines achieved and the deep and reactive logistic support available at the end of the most recent conflict in Afghanistan are less likely to be achieved during future conflicts. Hence, surgeons may be expected to manage patients for a longer period prior to evacuation, which for planning purposes can be defined as up to 5 days. The aim of this review and consensus group was to identify those surgical skills required for the acute management of combat injuries to the HFN region in a deployed military environment.

\section{METHOD}

A systematic review of the literature published between 1 January 2001 and 31 December 2015 was undertaken using the Preferred Reporting Items for Systematic Reviews and Meta-Analyses methodology to identify those surgical procedures necessary to manage head, face, neck and eye trauma in the deployed military environment. ${ }^{8}$ A search was made of web-based, online databases comprising PubMed, Web of Science, Medscape and Google Scholar. The following keywords were used: military, austere, damage control surgery, head, brain, ocular, eye, maxillofacial, face, cervical and neck. Only primary sources were included and the searches were confined to papers in the English language. Papers unrelated to the treatment of military personnel were excluded. The abstract of each article was reviewed and relevant articles were retrieved or copied in full for further evaluation, including a search of their bibliographies. This was followed by a multidisciplinary working group that aimed to achieve consensus regarding which skills are required at each point in the Operational Patient Care Pathway.

Procedures were subdivided by the clinical distinctions between DCS and 'In-theatre surgery'. The time planning guidelines described in the Operational Patient Care Pathway for in-theatre surgery were expanded so as to be reflective of the potentially protracted evacuation timelines in future conflicts. ${ }^{2}$ The following definitions were used.

\section{Damage control surgery}

Surgical procedures that need to be performed in order to halt progression of imminent life-threatening, limb-threatening and sight-threatening conditions.

\section{In-theatre surgery}

Surgical procedures that take place as part of ongoing injury management outside of immediate life, limb or sight salvage. Such surgical procedures halt physiological deterioration to allow safe evacuation to a definitive care facility.

\section{RESULTS}

Papers that identified potential training requirements for managing acute military head, face, neck and eye injuries ${ }^{3}$ 9-57 are shown in Figure 1. One systematic review was identified that discussed military facial bony, soft tissue and cervical vascular injuries using DCS principles. ${ }^{3}$ Three papers pertaining to DCS procedures were identified. ${ }^{383941}$

\section{Head and intracranial surgery}

Scalp lacerations should be appropriately debrided and may be closed. Scalp lacerations potentially contributing to haemodynamic instability require management as part of DCS. ${ }^{3}$ The need to be able to perform decompressive surgery for blunt traumatic brain injury (TBI) is based on civilian guidelines and is premised on diagnosis with appropriate cross-sectional imaging, and appropriate decision-making skills, as not all blunt TBIs need surgery. Two existing and pertinent key performance indicators were identified within the UK DMS pertaining to head and intracranial surgery: the debridement of penetrating head injury and closure within 6 hours, and decompressive craniectomy for blunt TBI being performed within 4 hours of injury. ${ }^{28}$

The concept of damage control neurosurgery (DCNS) was described by Rosenberg. ${ }^{262742}$ Two key factors felt to contribute to a better outcome after a severe brain injury were the prevention of secondary brain injury and evacuation of intracranial haematomas. The author points out that any surgery to remove compression (even if not a complete evacuation) was likely to be beneficial and therefore recommended craniectomy (as opposed to craniotomy) for non-neurosurgeons. The author also acknowledges the concern that such limited treatment may be complicated by cerebral swelling, but as a temporising tool it is considered effective. Teff described complications following decompressive neurosurgery having been performed by non-neurosurgeons while serving in Iraq. ${ }^{41}$ These included inappropriate surgery, wrongly sited craniotomies and other significant complications. This led to the development of a specific DCNS course for deployed American surgeons within Iraq, designed at teaching appropriate decision making, evaluation of CT scans, insertion of intracranial pressure (ICP) monitoring (to guide non-operative management) and subtemporal craniectomy to relieve brainstem swelling. This craniectomy was not seen as a definitive procedure, but again one to enable survival until further evacuation to a higher echelon of care.

Bell et al in their study of 408 postsurgical patients noted a paradigm shift in military surgery over the last 20 years. ${ }^{25}$ This was from a conservative or expectant attitude to severe wartime brain injury, to a rapid, far-forward aggressive and early decompressive surgical approach in dealing with both blunt trauma and penetrating trauma. The clinical outcomes of such treated patients were expected to be devastating, but most patients achieved a GCS score of 4 or 5 at 6-month follow-up, which was much better than anticipated. Surgery was not always early 


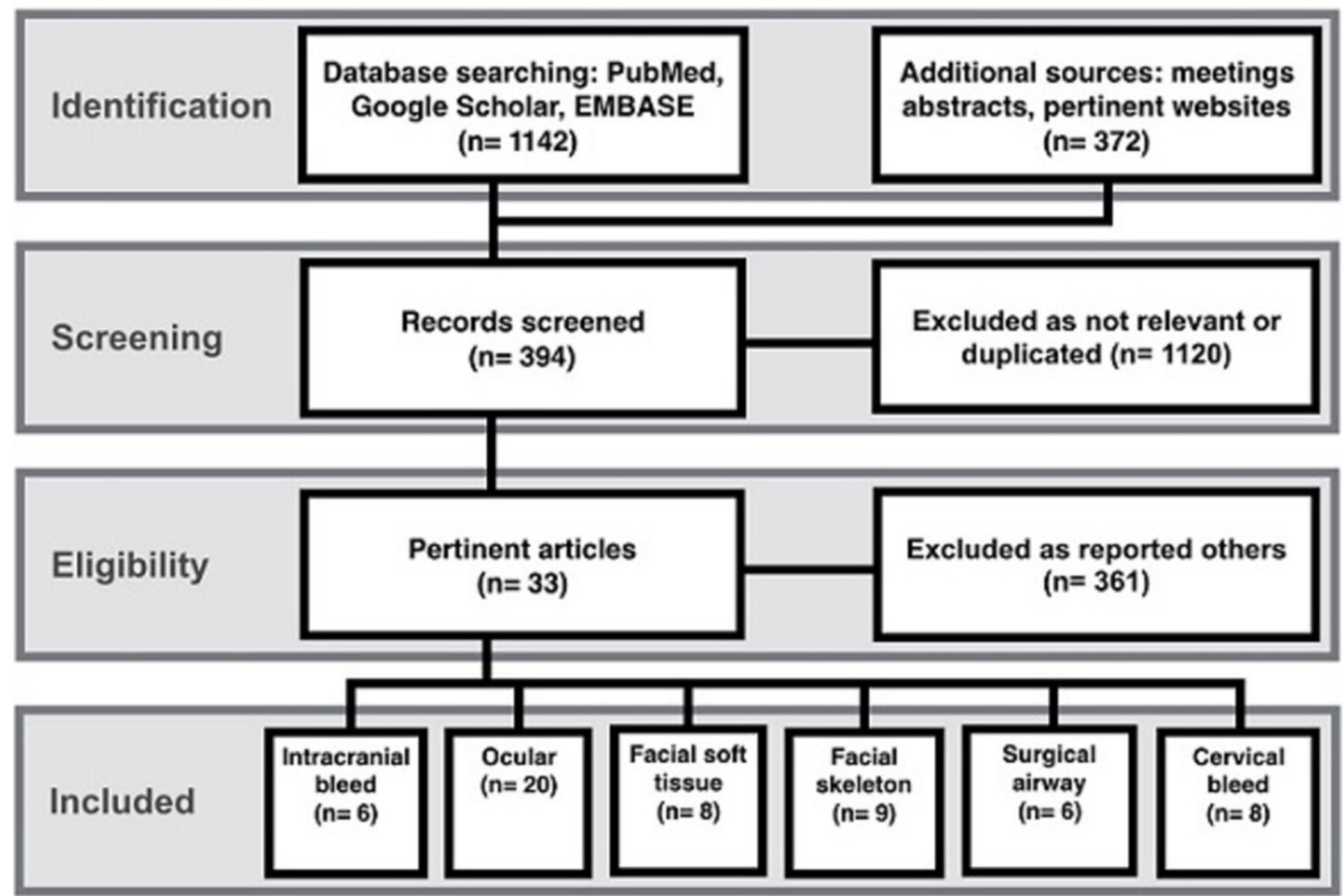

Figure 1 The results of the literature undertaken using the Preferred Reporting Items for Systematic Reviews and Meta-Analyses methodology. ${ }^{8}$

and it was noted some patients had their surgery once back in the continental USA. However, the risk of delayed deterioration, especially with long evacuation times meant there was a move to undertake surgery early in the majority of cases. The authors also noted the importance of early decision making and careful operative planning, including determining suitable sizes of bone flaps, early treatment of the anterior air sinuses and making use of Kempe's incision. Ragel et al described the lessons of performing such wartime decompressive craniectomies, highlighting their value in the safe transportation of patients and also recommended the use of Kempe's incision in wartime cases. ${ }^{43}$ Ragel et al also published their 2-year experience from Bagram Airfield where they undertook 325 cases, of which 138 were craniotomies. ${ }^{44}$ The paper also commented on the low threshold for decompressive surgery, and while the exact breakdown of types of operation is not given, note should be made that the minor procedures included ventriculostomies and ICP monitor insertion. Multiple papers commented on the difficulties of managing neurosurgical patients over long retrieval distances. ${ }^{45-47}$ Having an adequate 'reach-back' service is highlighted by Dulou et al, including making use of surgical planning within a Role 4 environment and forwarding surgical plans electronically. ${ }^{47}$ Also noted is the use of moving appropriately trained surgeons forward to the casualty on a need-to-treat basis. 47

\section{Ophthalmic surgery}

Lateral canthotomy with cantholysis is required to decompress retrobulbar haemorrhage within 2 hours of onset in order to prevent irreversible retinal ischaemia. ${ }^{48} \mathrm{~A}$ retrospective review of patients injured in terrorist events and conflict-related injuries treated in a military hospital in Turkey demonstrated 'favourable' visual outcomes in $58 \%$ of patients treated within 24 hours versus $45 \%$ if surgery was performed after 24 hours, a dichomotous outcome difference of $13 \% .{ }^{49}$ The use of fibrin glue for the repair of open globe injuries with small perforations was described in a small American case series. ${ }^{50}$ Intraocular foreign body removal can be delayed for a number of days, so long as primary repair is performed and adequate antibiotic cover is given. ${ }^{51} 52$ Both evisceration (by which all intraocular contents are removed while preserving the remaining scleral shell) and enucleation were described for irreparable ocular damage. ${ }^{29} 32505153$ Only a single case of sympathetic ophthalmia from both British and American operations in Iraq and Afghanistan was identified and was attributed to inadequate evisceration. ${ }^{54}$ Protection of penetrating eye wounds by secondary eye protection and delayed lateral canthotomy was recommended. ${ }^{3637}$

\section{Neck surgery}

A surgeon with skills capable of arresting cervical haemorrhage within 30 min of arrival at a Medical Treatment Facility

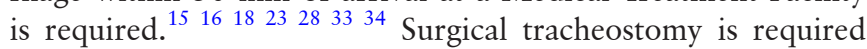
to provide a definitive airway, particularly when upper airway trauma or significant neck injury prevents conventional endotracheal intubation. ${ }^{16}$ 18-20 23 Pedicled flaps have been used as durable soft tissue coverage for local nationals being treated in the field hospital setting, but not for injuries to the head, face or neck. ${ }^{40}$ Free flaps to the face and neck area have been used 


\begin{tabular}{|c|c|c|}
\hline \multirow[t]{3}{*}{ Damage control surgery } & Airway & Surgical cricothyroidotomy \\
\hline & Haemorrhage & Neck access, packing, vessel ligation, vessel repair, scalp lacerations \\
\hline & Eye injury & Lateral canthotomy and cantholysis \\
\hline \multirow{5}{*}{$\begin{array}{l}\text { Acute in-theatre surgery } \\
(<24 \text { hours })\end{array}$} & Airway & Surgical tracheostomy \\
\hline & Soft tissue injury & Debridement, cleaning and decontamination, packing, tension-free primary closure \\
\hline & Bone injury & $\begin{array}{l}\text { Stabilisation of grossly mobile facial bone fragments to protect the airway or control haemorrhage, debridement of open } \\
\text { fractures to prevent infection, extraction of loose and damaged teeth to protect the airway }\end{array}$ \\
\hline & Eye injury & Primary globe repair \\
\hline & Brain injury & Limited decompressive craniectomy, debridement of penetrating wound, intracranial pressure monitoring* \\
\hline \multirow{4}{*}{$\begin{array}{l}\text { Delayed in-theatre surgery } \\
\text { ( } 24 \text { hours- } 5 \text { days) }\end{array}$} & Bone injury & Stabilisation of facial fractures using intermaxillary fixation, external fixation or internal fixation \\
\hline & Soft tissue injury & Serial debridement, delayed primary closure, contextually appropriate reconstruction, only if no higher echelon available \\
\hline & Eye injury & Delayed lateral canthotomy, evisceration, enucleation, eyelid repair \\
\hline & Brain injury & Formal decompressive craniectomy \\
\hline
\end{tabular}

*Dependent on diagnostic CT scanning being available.

by American military surgeons and were described in three papers. $^{55-57}$

\section{Facial surgery}

Mixed reports were found regarding management of facial soft tissue injury. Some British authors stated that wounds should be cleaned, decontaminated and repaired by delayed primary closure. ${ }^{1116} 18$ However, a comprehensive review of all British military facial injuries identified that debridement and primary direct closure under antibiotic cover failed to show any cases of postoperative infection. ${ }^{2}$ The use of both internal and external fixation techniques for maxillofacial fractures was described by British and American military surgeons for the early management of ballistic wounds. ${ }^{9101718}$ While technique choice depended on the degree of comminution and contamination, mandible and midfacial fracture stabilisation was felt to be a necessary skill in order to reconstitute the anatomy that enables an individual to protect their own airway. ${ }^{1718}$

\section{DISCUSSION}

Military HFN wounds can cause mortality and serious morbidity due to airway obstruction, cervical haemorrhage and the mass effect of intracranial haemorrhage. ${ }^{3-34}$ In addition, there is a risk to sight if an ocular injury is not managed appropriately. DCR and in-theatre surgical procedures were identified that should be performed on patients in the acute setting (Table 1). In-theatre surgery, for the purposes of this paper, has been subdivided into those acute procedures required within 24 hours and those that can be delayed up to 5 days. This is a clinically useful distinction and reflects the extended evacuation timelines that may occur in future conflicts. The greatest areas of discussion within the literature appeared to be in the management of penetrating ocular injury, the management of intracranial injury and the use of internal fixation for facial fractures because of staffing and resource issues associated with optimal management of these conditions in the deployed setting.

Focusing first on ophthalmic injury, the management of penetrating ocular trauma requires recognition of the extent of injury and specific surgical techniques to effect appropriate repair. A civilian study within the NHS has suggested that delaying primary repair of penetrating ocular injury beyond 12 hours increases the risk of endophthalmitis. While there was no military or austere medical evidence to support this time frame, ${ }^{58}$ a military series showed that delaying primary repair beyond 24 hours was associated with a $13 \%$ higher incidence of poorer outcomes. ${ }^{49}$
Primary globe repair within 24 hours should be the standard of care aspired to, although it is recognised that such expertise may not be immediately available (Table 1). Corneal gluing has a limited role for those correctly trained in its use for the repair of small, simple, isolated corneal wounds. Lid lacerations may occasionally be associated with injuries to the lacrimal drainage system and levator palpebrae superioris muscle. However, significant lid lacerations may be left for up to 1 week, so long as the cornea is protected from desiccation. In relation to unsalvageable ocular injury, evisceration may be indicated but enucleation rarely is. Evisceration should be performed where primary repair is not possible because of insufficient remaining ocular tissue, but this decision should be made in consultation with a surgeon competent to perform primary repair. Both enucleation and evisceration can safely be delayed for up to 14 days if haemorrhage is controlled.

Without CT scanning, neurotrauma management is based around the debridement of open injuries and the creation of exploratory burr holes. Burr holes are generally reserved for patients with closed head injuries who are deteriorating, with localising neurological signs. Burr holes can be converted to a craniectomy to allow evacuation of haematomas, and in theory also to decompress the brain, enabling transfer for more definitive surgery. ${ }^{2741}$ If CT scanning is available, then treatment can be directed and refined, including the insertion of ICP monitoring devices and the performance of decompressive surgery. This may be a directed, limited decompression (craniectomy) in the first instance to allow evacuation of the patient to a neurosurgeon, or a larger unilateral or bilateral decompression to evacuate haematomas and/or reduce ICP at a later stage. It is important to note that, as well as knowing how to perform the technical aspects of any procedure, appropriate decision-making skills are essential, as non-operative management may be more appropriate. Decompressive cranial surgery is not a benign procedure and decisions should be made in conjunction with the anaesthetic or critical care team. Authors in the USA consider that there has been a paradigm shift in the treatment of TBI, from expectant care towards aggressive far-forward surgery with good outcomes. ${ }^{25}$ Both telemedicine and forward transfer of neurosurgeons as required have been used by the French Armed Forces to bridge the gap in managing TBI in the absence of neurosurgical expertise. ${ }^{47}$

There was a difference in the use of internal fixation to treat facial fractures in the acute setting between authors in the USA and the UK. A review of 35 British civilian hospitals in 2016 
demonstrated that the mean time from injury to mandible fracture internal fixation is currently 22 hours. ${ }^{59}$ However, this may not reflect some of the high energy transfer injuries seen secondary to ballistic injury. In an American field hospital in Iraq, a review of 241 mandible, midface and frontal bone fractures treated by internal fixation showed that $46 \%$ were treated prior to evacuation and none developed a postoperative infection. ${ }^{35}$ It has been the experience of British authors that internal fixation in ballistic injury should be delayed until 3-5 days after injury ${ }^{18}$; this would be an appropriate balance between potential infection and further tissue devascularisation, versus the need to stabilise bone fragments that may otherwise hamper the airway and nutrition. Skills are required to stabilise (but not necessarily formally fix) facial fractures to enable self-maintenance of the airway and hence extubation when possible. This can rapidly free up valuable intensive care space and ensures that patients do not remain intubated for longer than is absolutely necessary. It may result in reduced equipment and medical manpower requirements during onward strategic or tactical 'medevac'. However, in situations where aeromedevac is rapid (such as was seen in the mature Afghanistan conflict setting), then aeromedevac of severe facial injuries intubated and with unfixed fractures is appropriate.

The DMS 2020 review and SDSR 15 determined that in future UK military deployments a full 'head and neck' surgical team will likely be unavailable within a deployed medical treatment facility. The treatment of HFN wounds to a standard comparable with or above that achieved in the UK requires skill sets normally outside that of a single surgical specialty (Table 1). This suggests a requirement to extend the competencies of appropriate groups of surgeons, beyond those acquired during their civilian training, and crossing established surgical specialty boundaries. Such a dilemma has already been faced by recently accredited general surgeons, who lack the broad-based training of their predecessors in vascular, thoracic, abdominal and urological surgeries due to changes in modern surgical training. ${ }^{6061}$ Further work is required to identify the extent to which head and neck skills are transferable between disciplines. The ability to recognise indications for procedures and manage their complications is at least as important as acquiring procedural skills. The identification of those skill sets required for deployment is in keeping with the General Medical Council's current drive towards credentialing consultants, by which a consultant surgeon's capabilities in particular practice areas would be defined. ${ }^{2}$ Credentialing is 'a process which provides formal accreditation of attainment of competences (which include knowledge, skills and performance) in a defined area of practice, at a level that provides confidence that the individual is fit to practise in that area'. In particular, credentialing will aim to recognise the particular capabilities of consultant surgeons over and above their Certificate of Completion of Training.

Limited opportunities currently exist for trainees and consultants to gain experience in the management of those types of head and neck injury seen during combat operations, including those working in MTCs. ${ }^{63}$ Predeployment exercises with European nations, ${ }^{63}$ the Military Operational Surgical Training (MOST) course and other courses can go same way to mitigate the risk. Historically, there were separate neurosurgical and maxillofacial workshops which now form part of the MOST course. Two DCNS courses have recently been delivered separately to MOST, recognising that MOST alone cannot cover the breadth and depth of the required decision-making. Short, laboratory-based courses, however, cannot provide surgeons with all of the skills necessary to recognise indications for trauma-related procedures and to perform those procedures safely and competently. ${ }^{18}$ This skills and knowledge shortfall has become more acute with the planned loss of neurosurgery, otolaryngology and ophthalmic surgeons from regular DMS liability. The required level of competency can only be achieved by extended training and regular practice of the skills required by trainers and trainees with a commitment to the providing deployed medical care. Identification of training requirements for military surgeons, as well as maintaining skills for established consultants, is essential to ensure that the deployed team achieves these competencies. ${ }^{64} 65$ Potential solutions may include the establishment of tailored military HFN training or the development of military-specific surgical fellowships such as exist in the USA. Clearly articulating the need for ongoing training could be reflected in individual consultant job plans and could maintain operational effectiveness despite the changing nature of contemporary conflict and within current financial constraints. ${ }^{66}$ Finally, surgeons within individual specialties have varied competencies. Intelligent tasking to deploy individuals with complementary abilities, if feasible, could mitigate potential competency gaps.

Contributors Planning: JB, AJG, JGC. Conducting: JB, RB, JB, AMM, SEH, SR, AG, NM, AJG, SH, JGC, RFR. Reporting: JB, RB, JB, AMM, SEH, SR, AG, NM, AJG, SH, JGC, RFR.

Competing interests None declared.

Provenance and peer review Not commissioned; internally peer reviewed.

(c) Article author(s) (or their employer(s) unless otherwise stated in the text of the article) 2018. All rights reserved. No commercial use is permitted unless otherwise expressly granted.

\section{REFERENCES}

1 Khan M, Streets C, Tai N, et al. United Kingdom military surgical preparedness for contingency operations. J Trauma Acute Care Surg 2017;83:S142-4.

2 Bricknell M. For debate: the operational patient care pathway. J R Army Med Corps 2014;160:64-9.

3 Tong DC, Breeze J. Damage control surgery and combat-related maxillofacial and cervical injuries: a systematic review. Br J Oral Maxillofac Surg 2016;54:8-12.

4 Allied Joint Doctrine for Medical Support. Ministry of defence, 2017:1-280.

5 Midwinter MJ. Damage control surgery in the era of damage control resuscitation. $J R$ Army Med Corps 2009;155:323-6.

6 Bricknell M. The operational patient care pathway: joint service publication 950, 2014:1-25.

7 Soubry A. Defence Medical Services 2020 project, 2016:1-2. http://www.parliament. uk/business/publications/written-questions-answers-statements/written-question/ Commons/2014-12-05/217325/ (accessed 13 Oct 2016).

8 Moher D, Liberati A, Tetzlaff J, et al. Preferred reporting items for systematic reviews and meta-analyses: the PRISMA statement. J Clin Epidemiol 2009;62:1006-12.

9 Breeze J, Gibbons AJ, Hunt NC, et al. Mandibular fractures in British military personnel secondary to blast trauma sustained in Iraq and Afghanistan. Br I Oral Maxillofac Surg 2011:49:607-11.

10 McVeigh $\mathrm{K}$, Breeze J, Jeynes $\mathrm{P}$, et al. Clinical strategies in the management of complex maxillofacial injuries sustained by British military personnel. J R Army Med Corps 2010;156:110-3

11 Breeze J, Gibbons AJ, Combes JG, et al. Oral and maxillofacial surgical contribution to 21 months of operating theatre activity in Kandahar Field Hospital: 1 February 200731 October 2008. Br J Oral Maxillofac Surg 2011;49:464-8.

12 Wordsworth M, Thomas R, Breeze J, et al. The surgical management of facial trauma in British soldiers during combat operations in Afghanistan. Injury 2017;48:70-4.

13 Breeze J, McVeigh K, Lee JJ, et al. Management of maxillofacial wounds sustained by British service personnel in Afghanistan. Int I Oral Maxillofac Surg 2011;40:483-6.

14 Breeze J, Bryant D. Current concepts in the epidemiology and management of battlefield head, face and neck trauma. J R Army Med Corps 2009:155:274-8.

15 Breeze J, Gibbons AJ, Shieff C, et al. Combat-related craniofacial and cervical injuries: a 5-year review from the British military. J Trauma 2011;71:108-13.

16 Breeze J, Monaghan AM, Williams MD, et al. Five months of surgery in the multinational field hospital in Afghanistan with an emphasis on oral and maxillofacial injuries. J R Army Med Corps 2010;156:125-8.

17 Gibbons AJ, Mackenzie N, Breederveld RS. Use of a custom designed external fixator system to treat ballistic injuries to the mandible. Int I Oral Maxillofac Surg 2011:40:103-5.

18 Gibbons AJ, Mackenzie N. Lessons learned in oral and maxillofacial surgery from British military deployments in Afghanistan. J R Army Med Corps 2010;156:113-6. 
19 Powers DB, Will MJ, Bourgeois SL, et al. Maxillofacial trauma treatment protocol. Oral Maxillofac Surg Clin North Am 2005;17:341-55.

20 Powers DB. Distribution of civilian and military maxillofacial surgical procedures performed in an Air Force theatre hospital: implications for training and readiness. J $R$ Army Med Corps 2010;156:117-21.

21 Cho RI, Bakken HE, Reynolds ME, et al. Concomitant cranial and ocular combat injuries during Operation Iraqi Freedom. J Trauma 2009;67:516-20.

22 Reed BE, Hale RG. Training Australian military health care personnel in the primary care of maxillofacial wounds from improvised explosive devices. J R Army Med Corps 2010;156:121-4.

23 Hale RG, Hayes DK. Combat Casualty Care: Lessons Learned from OEF and OIF. Maxillofacial and Neck Trauma: Borden Institute, 2012:1-74.

24 Roberts SA, Toman E, Belli A, et al. Decompressive craniectomy and cranioplasty: experience and outcomes in deployed UK military personnel. Br J Neurosurg 2016;30:529-35.

25 Bell RS, Mossop CM, Dirks MS, et al. Early decompressive craniectomy for severe penetrating and closed head injury during wartime. Neurosurg Focus 2010;28:E1.

26 Rosenfeld JV. How will we produce the next generation of military surgeons? Re: skill sets and competencies for the modern military surgeon: lessons from UK military operations in Southern Afghanistan. Injury 2010;41:435-6.

27 Rosenfeld JV. Damage control neurosurgery. Injury 2004;35:655-60.

28 Marsden $M E$, Sharrock $A E$, Hansen $C L$, et al. British Military surgical key performance indicators: time for an update? J R Army Med Corps 2016;162:373-8.

29 Ansell MJ, Breeze J, McAlister VC, et al. Management of devastating ocular trauma-experience of maxillofacial surgeons deployed to a forward field hospital. J R Army Med Corps 2010;156:106-9.

30 Blanch RJ, Bindra MS, Jacks AS, et al. Ophthalmic injuries in British Armed Forces in Iraq and Afghanistan. Eye 2011;25:1-6.

31 Blanch RJ, Scott RA. Military ocular injury: presentation, assessment and management. J RArmy Med Corps 2009;155:279-84.

32 Thach $A B$, Johnson AJ, Carroll RB, et al. Severe eye injuries in the war in Iraq, 2003-2005. Ophthalmology 2008;115:377-82.

33 Breeze J, Allanson-Bailey LS, Hunt NC, et al. Mortality and morbidity from combat neck injury. J Trauma Acute Care Surg 2012;72:969-74.

34 Chan RK, Siller-Jackson A, Verrett AJ, et al. Ten years of war. J Trauma Acute Care Surg 2012;73:S453-S458

35 Keller MW, Han PP, Galarneau MR, et al. Characteristics of maxillofacial injuries and safety of in-theater facial fracture repair in severe combat trauma. Mil Med 2015; 180:315-20.

36 Enzenauer RW, Vavra DE, Butler F. Combat ophthalmology. When there isn't an assigned ophthalmologist. Binocul Vis Strabismus Q 2007;22:153-68.

37 Mazzoli RA, Gross KR, Butler FK. The use of rigid eye shields (Fox shields) at the point of injury for ocular trauma in Afghanistan. J Trauma Acute Care Surg 2014:77:S156-S162.

38 Kuhn F, Slezakb Z. Damage control surgery in ocular traumatology. Injury 2004;35:689-95.

39 Krausz AA, Krausz MM, Picetti E. Maxillofacial and neck trauma: a damage control approach. World J Emerg Surg 2015:10:31.

40 Hanna K, Jeffery S. Radial forearm flaps as durable soft tissue coverage for local nationals being treated in the field hospital setting. J R Army Med Corps 2013;159:21-3.

41 Teff RJ. Use of neurosurgical decision-making and damage-control neurosurgery courses in the Iraq and Afghanistan conflicts: a surgeon's experience. Neurosurg Focus 2010;28:E9.

42 Rosenfeld JV. A neurosurgeon in Iraq: a personal perspective. J Clin Neurosci 2006;13:986-90.

43 Ragel BT, Klimo P, Martin JE, et al. Wartime decompressive craniectomy: technique and lessons learned. Neurosurg Focus 2010;28:E2.
44 Ragel BT, Klimo P, Kowalski RJ, et al. Neurosurgery in Afghanistan during "Operation Enduring Freedom": a 24-month experience. Neurosurg Focus 2010;28:E8.

45 Eisenburg MF, Christie M, Mathew P. Battlefield neurosurgical care in the current conflict in southern Afghanistan. Neurosurg Focus 2010;28:E7.

46 Mauer UM, Kunz U. Management of neurotrauma by surgeons and orthopedists in a military operational setting. Neurosurg Focus 2010;28:E10.

47 Dulou R, Dagain A, Delmas JM, et al. The French mobile neurosurgical unit. Neurosurg Focus 2010;28:E13.

48 Ballard SR, Enzenauer RW, O'Donnell T, et al. Emergency lateral canthotomy and cantholysis: a simple procedure to preserve vision from sight threatening orbital hemorrhage. J Spec Oper Med 2009;9:26-32.

49 Sobaci G, Mutlu FM, Bayer A, et al. Deadly weapon-related open-globe injuries: outcome assessment by the ocular trauma classification system. Am J Ophthalmol 2000;129:47-53

50 Weichel ED, Colyer MH, Ludlow SE, et al. Combat ocular trauma visual outcomes during operations iraqi and enduring freedom. Ophthalmology 2008:115:2235-45.

51 Colyer MH, Weber ED, Weichel ED, et al. Delayed intraocular foreign body remova without endophthalmitis during operations Iraqi freedom and enduring freedom. Ophthalmology 2007;114:1439-47.

52 Thach AB, Ward TP, Dick JS, et al. Intraocular foreign body injuries during operation Iraqi freedom. Ophthalmology 2005;112:1829-33.

53 Colyer $\mathrm{MH}$, Chun DW, Bower KS, et al. Perforating globe injuries during operation Iraqi Freedom. Ophthalmology 2008;115:2087-93.

54 Birnbaum AD, Tessler HH, Goldstein DA. Sympathetic ophthalmia in operation Iraqi freedom. Am J Ophthalmol 2010;150:758-9.

55 Klem C, Sniezek JC, Moore B, et al. Microvascular reconstructive surgery in operations iraqi and enduring freedom: The us military experience performing free flaps in a combat zone. J Trauma 2013;75:S228-32.

56 Chattar-Cora D, Perez-Nieves R, McKinlay A, et al. Operation Iraqi freedom: a report on a series of soldiers treated with free tissue transfer by a plastic surgery service. Ann Plast Surg 2007:58:200-6.

57 Geiger S, McCormick F, Chou R, et al. War wounds: lessons learned from operation Iraqi freedom. Plast Reconstr Surg 2008;122:146-53.

58 Essex RW, Yi Q, Charles PG, et al. Post-traumatic endophthalmitis. Ophthalmology 2004; 111:2015-22.

59 Katsarelis H, Lees T, McLeod N. Mandibular fractures - towards a national standard for "time to theatre" - national audit by the BAOMS Trauma Specialist Interest Group. $\mathrm{Br}$ J Oral Maxillofac Surg 2016;54:796-800.

60 Rew DA, Clasper J, Kerr G. Surgical workload from an integrated UK field hospital during the 2003 Gulf conflict. J R Army Med Corps 2004;150:99-106.

61 O'Reilly D, Lordan J, Streets C, et al. Maintaining surgical skills for military general surgery: the potential role for multivisceral organ retrieval in military general surgery training and practice. J R Army Med Corps 2016;162:236-8.

62 Marchant R. Credentialing consultation: Results and next steps. General medical council. 2016 http://www.gmc-uk.org/06__Credentialing_consultation__results and_next_steps.pdf_65711404.pdf

63 Brooks AJ, Ramasamy A, Hinsley D, et al. Military general surgical training opportunities on operations in Afghanistan. Ann R Coll Surg Eng/ 2009;91:417-9.

64 Pasquier $\mathrm{P}$, Dubost $\mathrm{C}$, Boutonnet $\mathrm{M}$, et al. Predeployment training for forward medicalisation in a combat zone: the specific policy of the French Military Health Service. Injury 2014;45:1307-11.

65 Bonnet S, Gonzalez F, Mathieu L, et al. The French Advanced Course for Deployment Surgery (ACDS) called Cours Avancé de Chirurgie en Mission Extérieure (CACHIRMEX): history of its development and future prospects. J R Army Med Corps 2016;162:343-7

66 Bowyer MW. Surgical education in the new millennium: the military perspective. Surg Clin North Am 2004;84:1453-70. 